\title{
APLIKASI GAME QUIZ ANIMALS BERBASIS WINDOWS 8
}

\author{
Yulyani Arifin; Budi Handoko; Venansius Kevin Nurtanio \\ Computer Science Department, School of Computer Science, Binus University \\ Jl. K.H. Syahdan No. 9, Palmerah, Jakarta Barat 11480 \\ yulyani_arifin@yahoo.com
}

\begin{abstract}
Game is currently in great demand by various circles, especially children. Children's interest in the game can be used as a tool to increase children's intellectuality, i.e. English competence. The purpose of this study is to design an animal-themed quiz game in English languange based on Windows 8 operating system, followed by making a game prototype designed. This game is expected to be an exciting educational tool for children in learning English and broadening the knowledge about types of animal. The research is conducted through the stages of game design requirements, game design, evaluation and implementation. Based on the results of the evaluation it is found that thoroughly the game already meets the standards of IMK by Shneiderman and Plaisant (2010). It is good enough as a game play since it is available at Window Store.
\end{abstract}

Keywords: game design, game quiz, Windows 8, English, IMK

\begin{abstract}
ABSTRAK
Game saat ini sangat diminati oleh berbagai kalangan khususnya anak-anak. Ketertarikan anak-anak pada game dapat dijadikan sebagai sarana edukatif untuk peningkatan kemampuan anak-anak contohnya di bidang Bahasa Inggris. Tujuan dari penelitian ini adalah untuk merancang quiz game yang bertemakan jenisjenis hewan dalam Bahasa Inggris berbasiskan sistem operasi Window 8, dan membuat prototype game yang dirancang. Game ini diharapkan dapat menjadi sarana edukatif yang menarik bagi anak-anak untuk mempelajari bahasa Inggris dan mengenal jenis hewan. Penelitian ini dilakukan melalui tahapan game design requirement, game design, dan testing and implementation. Berdasarkan hasil evaluasi yang dilakukan pada tahap akhir didapatkan bahwa game ini sebagian besar sudah memenuhi standar IMK menurut Shneiderman dan Plaisant (2010), dan sudah bagus dalam hal game play karena sudah masuk dalam Window Store.
\end{abstract}

Kata kunci: desain game, game kuis, Windows 8, Bahasa Inggris, IMK 


\section{PENDAHULUAN}

Anak-anak sejak dini mudah sekali diajari beragam bahasa. Salah satunya adalah Bahasa Inggris. Dengan alat yang menarik dan tampilan gambar yang menghibur akan membuat anak-anak menyukai pelajaran. Game didefinisikan sebagai salah satu tipe aktifitas bermain, di mana terdapat pemain, dan pemain berusaha untuk memenuhi tujuan sesuai dengan peraturan yang telah dirancangGame terbagi menjadi casual game dan hardcore game. Casual game lebih menekankan di permainan yang mudah untuk dimainkan, dan biasanya tidak membutuhkan perhatian yang serius dari segi waktu dan keseringan dalam bermain. Kebalikannya, hardcore game lebih menekankan pada aksi, grafik, dan biasanya membutuhkan keseriusan dalam bermain baik dari segi waktu bermain, maupun dari segi intensitas bermain (Adams, 2009).

Selanjutnya menurut Adams (2009), game terbagi menjadi beberapa genre. Action game yang lebih menekankan aksi dan reaksi dari pemain terhadap game dan kecepatan waktu pemain. Strategy game lebih menekankan pada cara mengatur resource yang dimiliki untuk mencapai goal yang diatur berdasarkan rules yang terdapat pada game. Role-Playing game lebih menekankan pada role-playing di mana setiap keputusan akan diambil oleh para pemain dan biasanya jalan cerita akan mengikuti jawaban keputusan yang diambil oleh para pemain. Sports game mengambil/melakukan imitasi terhadap kegiatan olahraga yang ada di dunia nyata seperti sepak bola, dll., di mana rules yang digunakan mengadopsi dari rules olahraga yang sudah ada. Simulation Game adalah game yang melakukan imitasi terhadap kehidupan sebenarnya seperti simulasi hidup simulasi berkendaraan. Adventure Game adalah game sejenis action game tapi lebih menekankan pada cerita akan petualangan-petuakangan.

Game menjadi salah satu pilihan untuk pembelajaran bagi anak-anak. Game yang sifatnya mendidik akan membantu anak-anak memahami apa yang diajarkan. Ditambah lagi dengan dukungan teknologi yang ada saat ini. Window 8 merupakan salah satu system operasi yang baru diluncurkan tahun lalu. Window 8 menyediakan tampilan antar muka yang lebih menarik dan mudah digunakan game dalam bentuk tablet maupun PC serta mendukung layar sentuh. Aplikasi game yang dibuat berbasis Window 8 akan menghasilkan satu aplikasi yang menarik dan mudah digunakan. Selain itu akan memudahkan bagi pengembang game untuk membuat game sederhana karena sudah banyak template yang disediakan.

\section{METODE}

Metodologi penelitian yang diusulkan terbagi menjadi tiga tahapan utama, yaitu: game design requirement, game design, dan testing and implementation.

\section{Game Design Requirement}

Tahapan ini adalah mencari kebutuhan yang ada di masyarakat, yaitu dengan cara menyebarkan kuisioner pada anak-anak dan melakukan evaluasi pada game sejenis secara individual untuk mencari kelebihan dan kekurangan game yang sudah ada.

\section{Game Design}

Tahapan ini bertujuan untuk merancang game berdasarkan hasil wawancara yang merupakan hasil dari tahapan sebelumnya. Pada tahap ini dirancang jalan permainan, layar tampilan dan hasil akhir dari game. 
Menurut Shneriderman dan Plaisant (2010,p32) terdapat lima faktor manusia terukur yang menjadi pusat evaluasi dalam merancang interface yaitu: (1) waktu belajar, yaitu berapa lama waktu yang dibutuhkan user untuk mempelajari bagaimana menggunakan perintah yang relevan; (2) kecepatan kinerja, yaitu berapa lama waktu yang diperlukan untuk menjalankan suatu tugas; (3) tingkat kesalahan user, yaitu berapa banyak dan apa saja kesalahan yang dibuat user dalam menjalankan suatu tugas; (4) daya ingat, yaitu seberapa baik user dapat mempertahankan pengetahuan mereka setelah jagka waktu tertentu, dan frekuensi dari penggunaan memegang peranan penting dalam hal ini; (5) kepuasan subjektif, yaitu mencari tahu apakah user senang menggunakan berbagai aspek dari sistem. Jawabannya dapat diperoleh melalui wawancara atau kuisioner yang memuat skala kepuasan dan tempat untuk memberi komentar.

Selain itu, menurut Shneidermn dan Plaisant (2010,p88-89), terdapat delapan golden rules of interface design: (1) konsistensi - perancangan user interface yang baik harus memperhatikan konsistensi dari penggunaan dan peletakan menu, warna, layout dan jenis huruf; (2) melayani kebutuhan universal - pengguna aplikasi sangat beragam sehingga dalam merancang aplikasi user interface harus mempertimbangkan perbedaan usia, gambatan fisik dan variasi teknologi. Jadi ada pemberian petunjuk untuk pengguna awam dan shortcut untuk pengguna yang sudah berpengalaman; (3) memberikan umpan balik yang informatif - untuk setiap aksi yang dilakukan oleh pengguna terhadap sistem, sistem harus memberikan umpan balik agar tercipta suasana yang komunikatif. Respon yang diberikan sesuai dengan aksi yang di lakukan baik itu besar atau kecil; (4) membuat dialog yang menghasilkan keadaan akhir - dalam perancangan komunikasi yang baik dengan pengguna, urutan tindakan harus diatur dengan mengetahui keadaan awal, tengah dan akhir; (5) adanya pencegahan kesalahan dan penanganan kesalahan - sistem yang dibuat dapat mencegah kesalahan fatal yang dilakukan oleh pengguna. Misalnya validasi yang terdapat pada formulir registrasi. Apabila pengguna melakukan kesalahan, sistem harus memberikan instruksi kepada pengguna bagaimana cara memperbaikinya; (6) memungkinkan pembalikan aksi dengan mudah system perancangan antar muka harus dapat mengembalikan aksi sebelumnya. Dalam suatu waktu, pengguna mungkin tidak sengaja melakukan aksi yang tidak diinginkan dan ingin melakukan pembatalan aksi. Dengan adanya fungsi pengembalian, pengguna dapat merasa nyaman dan tidak takut dalam menggunakan sistem; (7) mendukung pusat kendali internal - pengguna memiliki kekuasaan atas sistem, sehingga dapat mengontrol sistem dan sistem akan merespon tindakan yang dilakukan oleh pengguna; (8) mengurangi beban ingatan jangka pendek - tampilan harus dibuat sederhana sehingga dalam penggunaanya, pengguna tidak perlu banyak menghafal.

\section{Testing dan Implementation}

Pada tahapan ini akan dilakukan testing dan pembuatan prototype game. Selanjutnya akan dilakukan evaluasi berdasarkan faktor manusia untuk mengukur sejauh mana tingkat kepuasan dari pemakai game ini serta untuk mendapatkan feedback untuk pengembangan selanjutnya.

\section{HASIL DAN PEMBAHASAN}

\section{Game Design Requirement}

Pada tahap ini dilakukan penyebaran kuisioner untuk mengetahui kebutuhan anak-anak pada umumnya. Dari penyebaran kuisioner diketahui bahwa kebanyakan anak-anak menyukai game. Dan anak-anak lebih tertarik pada pengajaran dengan gambar atau suara. Jadi tidak terlalu tertarik jika pembelajaran hanya melalui bercerita atau konvensional saja. Dan jenis game yang sering dimainkan anak anak adalah dengan genre action maupun puzzle. 
Berikut adalah dua jenis game kuis trivia yang ada pada web yang akan dibandingkan. Pertama adalah Animal Trivia Quiz, yaitu game tebak-tebakan hewan dalam bahasa Inggris (Gambar 1) yang dapat diakses di http://www.factmonster.com/quizzes/animal-trivia/1.html. Game kedua adalah Usuk_wordsb, yaitu tebak-tebakan mengenai bahasa Inggris (Gambar 2) yang dapat diakses di http://www.sporcle.com/games/g/usuk wordsb.

\section{Animal Trivia Quiz}

Read more about Animals!
Question 1:
Which of these mammals lays eggs?
Oechidna
Obongo
Okiwi
Southern right whale
Answer \& Continue

Gambar 1 Tampilan game tebak-tebakan hewan

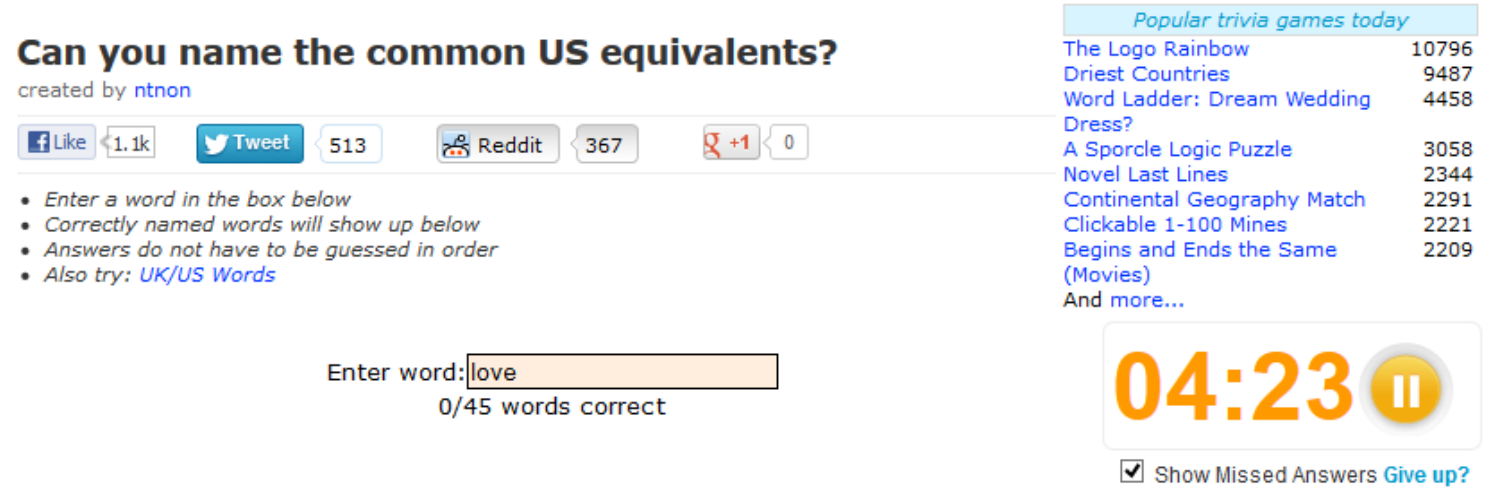

Gambar 2 Tampilan game tebak-tebakan mengenai bahasa Inggris

Perbandingan antara kedua games di atas sebagai berikut (Tabel 1):

Tabel 1 Perbandingan Game Animal Trivia dengan Usuk wordsb

\begin{tabular}{lll}
\multicolumn{1}{c}{ Aspek } & \multicolumn{1}{c}{ Animal Trivia Quiz } & \multicolumn{1}{c}{ Usuk_wordsb } \\
\hline Gambar & Tidak ada gambar & Tidak ada gambar \\
\hline Game Play & Tebak-tebakan & Tebak-tebakan \\
\hline Pengguna & Sulit dimainkan anak- anak & Sulit dimainkan anak-anak \\
\hline Bahasa & Inggris & Inggris \\
\hline
\end{tabular}

Dari perbandingan di atas, dua games tersebut secara umum hanya berupa teks; tidak ada tampilan gambar yang menarik. Kelebihan dua games tersebut adalah sudah menggunakan bahasa Inggris. Namun tingkat kesulitan lumayan tinggi untuk anak-anak. 


\section{Game Design}

Pada tahapan ini dirancang jalan cerita dari game yang akan dibuat. Game ini berupa tebaktebakan hewan berdasarkan kata yang muncul. Pengguna cukup memilih mana gambar yang sesuai dengan kata yang muncul. Apabila tebakannya benar, nilai bertambah. Namun jika tebakannya salah, nilai pun berkurang. Waktu yang diberikan kepada pengguna untuk berpikir juga terbatas. Sehingga apabila waktu sudah habis, pengguna dianggap tidak bisa menebak. Di bawah ini adalah beberapa tampilan layar yang dibuat (Gambar $3-7)$.

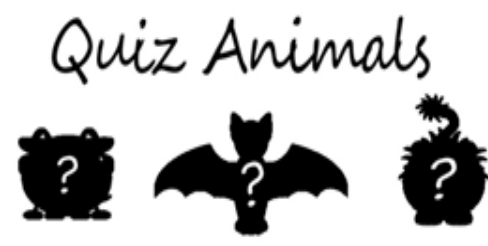

\section{START Quiz Animals}

Gambar 3 Layar Home

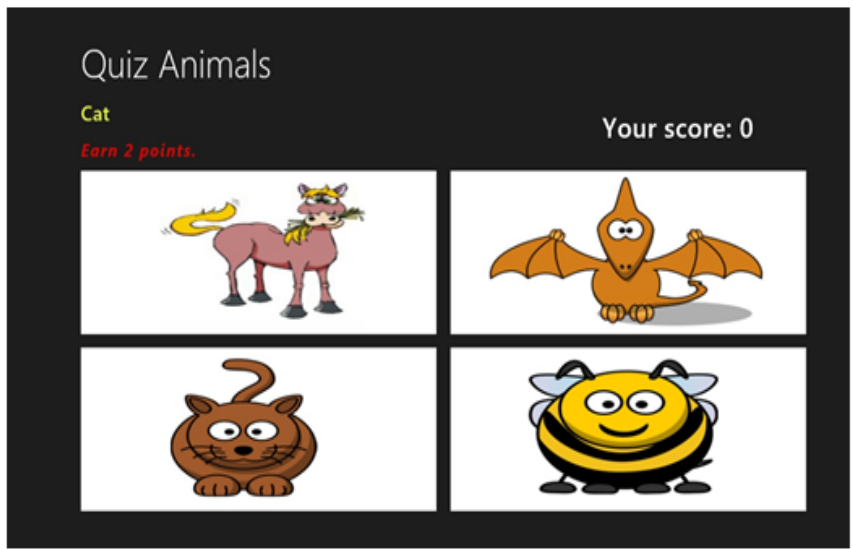

Gambar 4 Layar permainan

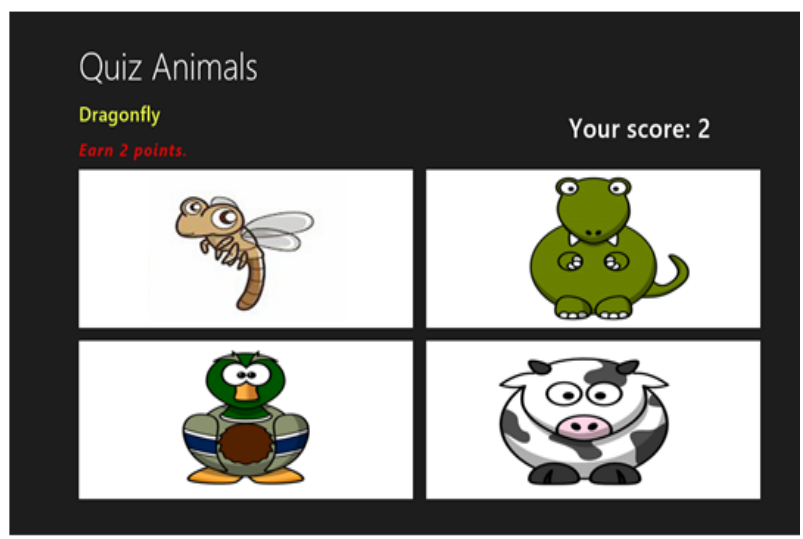

Gambar 5 Layar permainan yang salah 


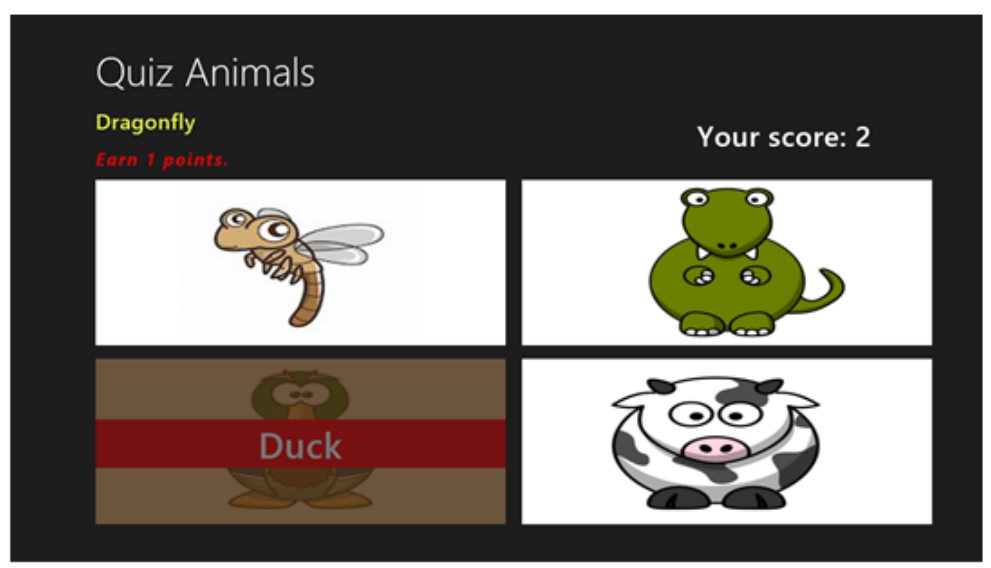

Gambar 6 Layar Permainan yang benar

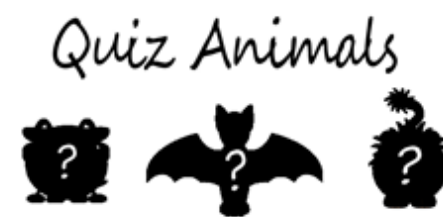

Thank you for playing! Your final score is...

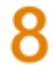

Restart Quiz Animals

Gambar 7 Layar Exit

\section{Evaluasi}

Untuk mendapatkan umpan balik dari pengguna, prototipe game diberikan kepada responden untuk dicoba dan dibagikan kuisioner untuk diisi. Dari hasil kuisioner evaluasi berdasarkan faktor manusia terukur yaitu: (1) dari segi waktu belajar, kebanyakan responden mudah mempelajari game dan tidak memerlukan waktu lama untuk menguasai game ini; (2) dari segi kecepatan kinerja, lebih dari 50\% responden menyelesaikan game ini dalam waktu kurang dari satu menit; (3) dari segi tingkat kesalahan user, jarang sekali responden melakukan kesalahan dalam bermain; (4) dari segi daya ingat, komponen yang mudah diingat oleh responden adalah gambar hewan yang ditampilkan; (5) dari segi kepuasan pemain, hampir semua responden puas dengan fitur yang ada pada game ini.

Berikut adalah hasil evaluasi berdasarkan 8 Golden Rules: (1) konsistensi: dari tampilan antar muka mulai dari awal permainan sampai akhir permainan selalu konsisten yaitu terdiri dari empat gambar. Dan desain antar muka menggunakan metro style; (2) melayani kebutuhan universal: tampilan nilai berupa angka umumnya mudah dimengerti oleh anak-anak. Dan tampilan gambar hewan yang menarik untuk anak-anak bahkan menarik juga untuk orang dewasa; (3) memberikan umpan balik yang informatif: pada saat pemain keliru memilih, ada tampilan pesan kesalahan sehingga pemain tahu bahwa sudah salah menebak; (4) membuat dialog yang menghasilkan keadaan akhir: pada saat memulai, nilai dimulai dengan angka 0, dan pada saat akhir permainan baru ditampilkan nilai seluruhnya sehingga pemain tahu bahwa sudah sampai pada akhir permainan; (5) adanya pencegahan kesalahan dan penanganan kesalahan: ada pesan kesalahan yang muncul jika pemain salah memainkan 
game; (6) memungkinkan pembalikan aksi dengan mudah: pemain cukup menekan tombol back jika ingin kembali ke keadaan sebelumnya; (7) mendukung pusat kendali internal: pemain bebas melanjutkan permainan atau mau keluar pada saat itu juga; (8) mengurangi beban ingatan jangka pendek: tampilan dibuat sederhana dan mudah diingat sehingga pemain yang cenderung anak-anak tidak perlu menghapal permainannya.

Aplikasi game ini sudah masuk dalam Window Store dan mendapat rating 5 (Gambar 8). Hal ini menandakan bahwa permainan ini disukai oleh pemakai.

\section{$\oplus$ Quiz Animals}

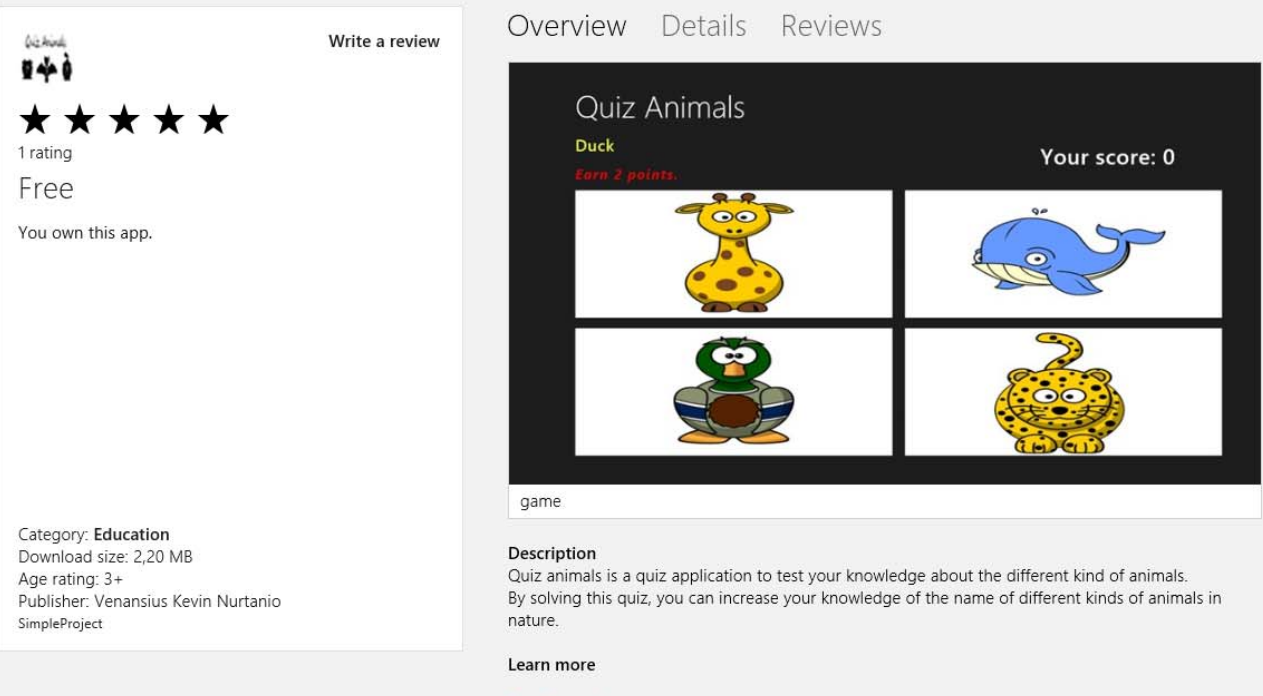

Gambar 8 Tampilan rating game

\section{PENUTUP}

Dalam penelitian ini dibuat sebuah protoptipe game untuk melatih kemampuan perbendaharaan kata hewan dalam bahasa Inggris. Game ini berupa tebak-tebakan nama hewan berdasarkan kata yang muncul. Pengguna cukup memilih mana gambar yang sesuai dengan kata yang muncul. Apabila tebakannya benar, nilai bertambah. Namun jika tebakannya salah, nilai pun berkurang. Waktu yang diberikan kepada pengguna untuk berpikir juga terbatas. Sehingga apabila waktu sudah habis, pengguna dianggap tidak bisa menebak. Berdasarkan hasil evaluasi yang dilakukan pada tahap akhir didapatkan bahwa game ini sebagian besar sudah memenuhi faktor manusia terukur dan 8 golden rules. Game ini terbukti berkualitas dengan rating 5 dalam Window Store.

\section{DAFTAR PUSTAKA}

Adams, Ernest. (2009). Fundamental of Game Design (2nd ed.). New Jersey: New Riders.

Shneiderman, B., \& Plaisant, C. (2010). Designing The User Interface: Strategies for Effective Human Computer Interaction. New Jersey: Addison-Wesley. 